\title{
Belgeo
}

\section{(Lifestyle) immigrant entrepreneurs in Spanish small villages: Rethinking international immigration in rural Alt Empordà, Catalonia}

Entrepreneurs immigrants (à la recherche d'une meilleure qualité de vie) dans de petits villages espagnols: Repenser l'immigration internationale dans les zones rurales de l'Alt Empordà, Catalogne

\section{Cristóbal Mendoza, Ricard Morén-Alegret and Ruth McAreavey}

\section{OpenEdition}

\section{Journals}

Electronic version

URL: http://journals.openedition.org/belgeo/44107

DOI: $10.4000 /$ belgeo.44107

ISSN: 2294-9135

Publisher:

National Committee of Geography of Belgium, Société Royale Belge de Géographie

\section{Electronic reference}

Cristóbal Mendoza, Ricard Morén-Alegret and Ruth McAreavey, "(Lifestyle) immigrant entrepreneurs in Spanish small villages: Rethinking international immigration in rural Alt Empordà, Catalonia", Belgeo [Online], 1 | 2020, Online since 03 December 2020, connection on 20 January 2021. URL: http:// journals.openedition.org/belgeo/44107 ; DOI: https://doi.org/10.4000/belgeo.44107

\section{This text was automatically generated on 20 January 2021.}

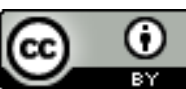

Belgeo est mis à disposition selon les termes de la licence Creative Commons Attribution 4.0 International. 


\section{(Lifestyle) immigrant entrepreneurs in Spanish small villages: Rethinking international immigration in rural Alt Empordà, Catalonia}

Entrepreneurs immigrants (à la recherche d'une meilleure qualité de vie) dans de petits villages espagnols: Repenser l'immigration internationale dans les zones rurales de l'Alt Empordà, Catalogne

Cristóbal Mendoza, Ricard Morén-Alegret and Ruth McAreavey

This paper is based upon the research project titled "HAMLETS. Immigration and Sustainable Development in Small Villages" (see: www.uab.cat/hamlets). This project was funded by the RecerCaixa Programme (2017-2020), mainly carried out from the Autonomous University of Barcelona (Universitat Autònoma de Barcelona UAB) and directed by Ricard Morén-Alegret. The RecerCaixa Programme is an initiative of 'la Caixa' Foundation and the Association of Public Universities in Catalonia (Associació Catalana d'Universitats Públiques, ACUP), Spain. The coauthors are also grateful to the interviewees, the Association of Small Villages in Catalonia (www.micropobles.cat) and the Association of Mountainous Municipalities in Spain (www.esmontanas.org) for their time and collaboration.

\section{Introduction}

In many parts of Europe, economic development presents a real challenge for rural areas. Localities may face depopulation alongside ageing. Not only can this hamper their economy but it may also make their territory more vulnerable to natural hazards (González-Hidalgo et al., 2014). In some of these rural areas, as the older population ceases to be economically active, their contribution to the local economy is not 
replaced due to the emigration of young people, leading to significant economic stagnation (Rye, 2006; Amcoff, Westholm, 2007). In this context, the potential of international immigrants for preventing (or at least slowing down) depopulation has been increasingly recognised in the literature (Bayona-i-Carrasco, Gil-Alonso, 2013; Woods, 2016; Morén-Alegret, 2008; Camarero, Sampedro, 2019). The arrival of international immigrants to rural areas has been a critical part of agricultural restructuring and wider socio-political and economic transformations across society.

2 This has led to profound changes in some rural communities across Europe. A growing body of literature examines the plight of a range of different types of immigrants in rural areas, including those working in agri-food or tourism, life-style/amenity immigrants and refugees (e.g. Bartoš et al., 2009; McAreavey, Argent, 2018; Rye, Scott, 2018; Morén-Alegret, Wladyka, 2019). Challenges facing immigrants settling in these non-urban spaces include the lack of knowledge and resources within the locality to appropriately accommodate increased diversity; relative isolation and invisibility of new arrivals; small overall numbers which perpetuate lack of institutional infrastructure, and the perception that they may negatively impact some ancient traditional lifestyles of the locally born population. While immigrants have been shown to fill gaps in the rural labour market, their potential to contribute to economic development with their skills, training, connections and, at times, their entrepreneurship is only beginning to be understood (Kalantaridis, Bika, 2011; Hedlund et al., 2017; Carson et al., 2018).

3 As result of these multifarious challenges, rural areas across Europe have faced significant transformations over recent decades. In the move to address demographic challenges and to shift away from sole reliance on agriculture, several economic activities have assumed heightened importance in making substantial contributions to the sustainability of many rural areas. Indeed, rural no longer equates to agriculture (Boyle, Halfacree, 1998). The multi-functional nature of rural areas continues to evolve; in many European countries rural areas have been transformed into places of consumption, preservation, experimentation, innovation and/or production. This functional transformation has led to a differentiated countryside where many different stakeholders have a legitimate interest in how the countryside is shaped (Marsden et al., 2003; Woods, 2016).

4 The integration of immigrants into these multi-functional and heterogeneous spaces can be a challenging process. Thus this paper studies connections between local economics, entrepreneurship and lifestyle immigration. It focuses on municipalities with fewer than 500 inhabitants in Alt Empordà, Catalonia, Spain. This type of scarcely populated municipality, that maintain a mayor with political power over fewer than 500 inhabitants, can usually be found in countries like France (communes) and Spain (municipios), but are not common in other European countries (Cloke, 2013). Specifically, the paper analyses the economic incorporation of immigrant entrepreneurs by considering the following research questions: In which ways do immigrant entrepreneurs contribute to the local economies and social fabric of small villages in Alt Empordà? To what extent do immigrant businesses follow purely economic benefit logics (or rather they are set up by lifestyle immigrants in search of a better quality of life)?

5 The paper is structured as follows. The next section theoretically analyses international immigration trends in rural settings as well as demonstrating how links between 
entrepreneurship and wellbeing among lifestyle immigrants are rarely studied in the academic literature. Subsequently the methodology used in the research project, upon which this paper is based, is outlined as well as key details about the main study area. The paper moves on to present the research results before analysing economic innovation in rural areas, social networking and the role of the territory. Finally, some conclusions and reflections for further research are offered. We find that the interviewed immigrant entrepreneurs - who are highly skilled European immigrants usually fit themselves in distinctive niches in local labour markets or economies (e.g. cultural-oriented services). Their success partially relies in their capacities for creating locally based social networks and, in some occasions, more permanent relations. These are not only key aspects for business development, but also a source of wellbeing. This is in line with most lifestyle immigration literature, which is developed in the next section.

\section{Theoretical framework: Lifestyle immigration and immigrant entrepreneurs}

6 Rural societies are often seen as more sedentary than urban regions (Bell and Osti, 2010). However, today this vision can fall into an urban stereotype based on traditional circumstances. It is only fairly recently that some non-metropolitan areas have experienced the relatively limited arrival of international immigration. Correspondingly, different 'categories' of migrants have arrived into rural areas, each of which exert different levels of agency in their negotiation of labour and regarding their social incorporation in the so-called New Immigration Destinations (McAreavey, 2017). These migration patterns may be associated to increasing mobilities in late modern societies (Hannam et al., 2006; Sheller and Urry, 2006). Nevertheless, not all migrants are captured by statistics, not all move in a linear fashion nor do they fit neatly into preconceived categories (Crawley, Skleparis, 2018). For this reason, there is some value in attempting to understand the different types of migration movements. Certainly, rural areas have been host to many different types of immigrants, including immigrant workers, retirees, entrepreneurs and lifestyle immigrants. Yet, an individual at the same time may match several of these categories, for instance being at once a retiree immigrant and an entrepreneur or working as a part-time employee while fulfilling lifestyle changes. In this article, we focus on lifestyle immigrant entrepreneurs; some of whom are retirees in their countries of origin.

7 Lifestyle migration and retirement migration are closely connected. Retirement migration is especially relevant in Southern Europe where Northern and Central European retirees head mainly for coastal areas with a benign climate and a history of seaside tourism (e.g. Portuguese Algarve, Spanish Costa del Sol; King et al., 2000; Williams et al., 2000). More recently, the combination of the so-called rural "idyllic" setting of a beautiful countryside with a supposedly laid-back lifestyle (e.g. rural South France, Italian Tuscany) has also attracted a relevant number of European retirees (King et al., 2019; Morén-Alegret, Wladyka, 2019). Retirement migration has been facilitated by an increase in geographic mobility; longer lifespans due to healthier lives; and more people pursuing active lifestyles through migration to countries perceived as scenically, climatically and culturally attractive and with affordable housing. This age related "lifestyle migration" is not only triggered by the desire to escape metropolitan 
life, it might also represent a search for a better quality of life (Benson and o'Reilly, 2016; Hayes, 2018). Lifestyle migrants have been defined as relatively affluent individuals of all ages, moving either part-time or full-time to places to achieve selffulfilment and secure a better quality of life (Benson, O'Reilly, 2009; Benson, Osbaldiston, 2014). It can be observed in peripheral rural areas of many world regions such as Latin America (e.g., Benson, 2013; Kordel, Pohle, 2018) and Southern Europe (e.g. Huete et al., 2013; Morén-Alegret et al., 2018).

Indeed, lifestyle immigrants may (re)enter labour markets and/or economies at destination, even after retirement (Eimermann, Kordel, 2018). These immigrants often seek self-employment, because they prefer being their own boss, as part of the new life that they envisaged, and thus maintain what they perceive as an acceptable work-life balance (Stone, Stubbs, 2007; Carson et al., 2018). Importantly, entrepreneurial activities undertaken by these migrants are most often a departure from their previous careers (Hoey, 2005). These businesses are often limited in both size and monetary terms, for fear that it may disturb the ideal work-life balance they have established (Benson, O'Reilly, 2009). This may have a limited impact on economic development, creating just a few job openings for the local population (Carson, Carson, 2018). Indeed, lifestyle entrepreneurs have been described as lacking business-oriented strategies and as being reluctant to employ workers beyond family and close friends (Müller, Jansson, 2007). Yet, lifestyle entrepreneurs have also been considered as instrumental in the creation and introduction of innovative products in specific niche markets that stimulate regional development and help to strengthen values concerning sustainability and a sense of place and community (Ateljevic, Doorne, 2000). Their appreciation of local resources and the genius loci, which is sometimes a major motivation for moving to rural areas (Bartoš et al., 2009; Iversen, Jacobsen, 2017), suggests that lifestyle immigrants have the potential to imagine local culture and nature as possible tourism products, as well as recognizing opportunities that local people might ignore (Bosworth, Farrell, 2011; Mattsson, Cassel, 2019).

The literature on lifestyle immigrant entrepreneurs has also pointed out that these immigrants contribute with new knowledge, resources and international contacts to local development, and have the potential to establish networks between their former home countries and new settings (Stam, 2010; Carson et al., 2018). This goes in line with the understanding of ethnic entrepreneurship from a "culturalist" approach. This understanding stresses the distinct group-specific cultural repertoire of businesspeople and self-employed workers in the form of cultural values, behavioural patterns, collective resources and coping strategies (Rath, Kloosterman, 2000; Zhou, 2004). It also emphasizes the role of intra-ethnic networks in entrepreneurship. Access to these social capital resources is associated with ethnic solidarity, based on expectations of mutual support between community members, which are united by cultural similarities and difficulties in accessing formal support systems (Faist, 2000; Sommer, Gamper, 2018).

10 Yet what has scarcely been studied is the capacity of immigrant entrepreneurs for creating social networks and relations in rural host societies. Indeed, they may be considered to be "welcomed" immigrants in areas suffering de-population and economic stagnation (Kordel, Pohle, 2018). In this sense, the idea of "opportunity structure" in host societies, proposed by Aldrich and Waldinger (1990) and later developed by Rath and Kloosterman (2000), seems a good framework for understanding 
business incorporation among Northwest and Central European immigrants in some rural areas of Southern Europe. In the specific case of immigrant entrepreneurs, the meso-level of the local opportunity structure may be combined with the micro-level of the specific characteristics of individual entrepreneurs and the macro-institutional framework (see also Kloosterman, 2010). Certainly, some rural areas might offer an innovative and entrepreneurial milieu in which small-scale enterprises may prosper (García Marchante et al., 2007; Stathopoulou et al., 2004). This may combine with immigrant entrepreneurs' fresh and innovative views on local culture and nature as possible products or brands (Mattsson, Cassel, 2019) in order to produce successful businesses. Thus, the article aims to explore the extent to which immigrant business follow an economic logic, seeking benefits and having possible spill over effects on local communities (or rather they are set up by lifestyle immigrants searching for better standards of living for whom the benefit rationale is subordinate)

\section{Methodology, methods and techniques}

This article examines foreign-born immigration and entrepreneurship in municipalities with fewer than 500 registered inhabitants. This paper is based upon a wider research project ${ }^{1}$ that aims to improve territorial relations and integration in Catalonia beyond the so-called rural-urban divide, recognising the importance of ruralurban functional linkages and the multitude of associated interconnections (OECD, 2018). The methodology consisted of multi-sited research in pre-selected case studies, employing both quantitative and qualitative methods.

This article specifically focuses on immigrant entrepreneurship and explores if immigrant businesses are instrumental in the search for a better quality of life - as the lifestyle immigrant literature suggests - or rather they follow an economic logic (or do both). In order to do so, the paper studies experiences, views and opinions of immigrant employers/self-employed workers on labour markets and economies in small villages. Immigrants were selected through a snowballing technique using contacts already held by the research team. However, to avoid bias, foreign-born immigrants were contacted using several approaches. All interviews were structured along three main dimensions: economic, social and environmental and lasted on average for one hour. Interviews were held in Catalan, Spanish and English, and they were audio-recorded at a time and place of the participant's choice during spring and summer 2019. Data was anonymised using codes and pseudonyms. Table 1 shows the eight women and four men interviewed for this project who were born in other European Union countries, including the UK (a member of the EU at the time of interview) and had been living for at least one year in a small village of Alt Empordà.

Table 1. Interviewed foreign-born entrepreneurs and self-employed workers in Alt Empordà.

\begin{tabular}{|l|l|l|l|l|l|l|}
\hline No & Sex & Age & $\begin{array}{l}\text { Interviewee Country } \\
\text { of Birth }\end{array}$ & $\begin{array}{l}\text { Marital Status \& Partner } \\
\text { Country of Birth }\end{array}$ & $\begin{array}{l}\text { Years in } \\
\text { Spain }\end{array}$ & $\begin{array}{l}\text { Economic Sector \& Professional } \\
\text { Category }\end{array}$ \\
\hline 1 & M & 66 & Germany & Single; Spain ${ }^{1}$ & 39 & $\begin{array}{l}\text { Tourism self-employed. } \\
\text { Retired employer }\end{array}$ \\
\hline
\end{tabular}




\begin{tabular}{|c|c|c|c|c|c|c|}
\hline 2 & $F$ & 71 & Germany & Widow; Spain ${ }^{2}$ & 19 & $\begin{array}{l}\text { Occasional teacher with } \\
\text { widow's pension }\end{array}$ \\
\hline 3 & $\mathrm{~F}$ & 48 & Italy & Married; Spain ${ }^{2}$ & 12 & Farming. Employer \\
\hline 4 & M & 58 & Italy & Single & 2 & Tourism. Employer \\
\hline 5 & M & 68 & Netherlands & Married; Spain ${ }^{3}$ & 20 & $\begin{array}{l}\text { Consultant. Self-employed. } \\
\text { Retired employee }\end{array}$ \\
\hline 6 & $F$ & 40 & UK & Married; Spain ${ }^{3}$ & 15 & Musician. Self-employed \\
\hline 7 & $\mathrm{~F}$ & 48 & Netherlands & Married; Netherlands & 15 & $\begin{array}{l}\text { Artist/teacher. } \\
\text { employed }\end{array}$ \\
\hline 8 & $\mathrm{~F}$ & 58 & Belgium & Married; Spain ${ }^{2}$ & 18 & Consultant. Self-employed \\
\hline 9 & $\mathrm{M}$ & 65 & Germany & Married; Spain ${ }^{3}$ & 33 & $\begin{array}{l}\text { Restaurant chef. Self- } \\
\text { employed. Retired employee }\end{array}$ \\
\hline 10 & $\mathrm{~F}$ & 58 & UK & Married; Spain ${ }^{1}$ & 30 & $\begin{array}{l}\text { Artist/consultant. } \\
\text { employed }\end{array}$ \\
\hline 11 & $\mathrm{~F}$ & 28 & Netherlands & Married; Netherlands & 2 & Farming. Employer \\
\hline 12 & $\mathrm{~F}$ & 41 & UK & Married; UK & 8 & $\begin{array}{l}\text { Language } \\
\text { Employer }\end{array}$ \\
\hline
\end{tabular}

\footnotetext{
1 Partner born in Alt Empordà.

${ }^{2}$ Partner with roots in Alt Empordà, but not born in the area

${ }^{3}$ Spanish partner with no roots in the area

Source: HAMLETS research project fieldwork, 2019
}

Interview data were analysed through a content analysis method. This has several phases, i.e. coding, labelling (with software MAXQDA), grouping, reading, analysing, abstracting and selecting relevant quotations to illustrate the main lines of analysis.

\section{Context for research: Alt Empordà, Catalonia}

In Catalonia, even if only $1.08 \%$ of the total population is residing in municipalities with fewer than 500 inhabitants, micro-villages constitute over a third (36\%) of the Catalan municipalities and the territory (INE, 2018). Accordingly, Figure 1 indicates the location of these little populated municipalities in Catalonia (mainly in mountain and inland areas) and also displays the percentage of foreign-born residents in them. Interestingly, Alt Empordà is one of the counties of Catalonia with the most micro-villages with high percentages of foreign-born population. Specifically, $15.3 \%$ of the inhabitants registered in hamlets of Alt Empordà are born outside of Spain, i.e. there are 1,190 foreign-born residents registered in small villages of Alt Empordà, including 493 born in the EU countries. The profile of these immigrants generally matches with a type of lifestyle immigration, i.e. related to second homes and partially associated with economic activities focusing on tourism (Romagosa et al., 2020). 
Figure 1. Foreign-born residents in 337 municipalities with fewer than 500 inhabitants in Catalonia (Spain).

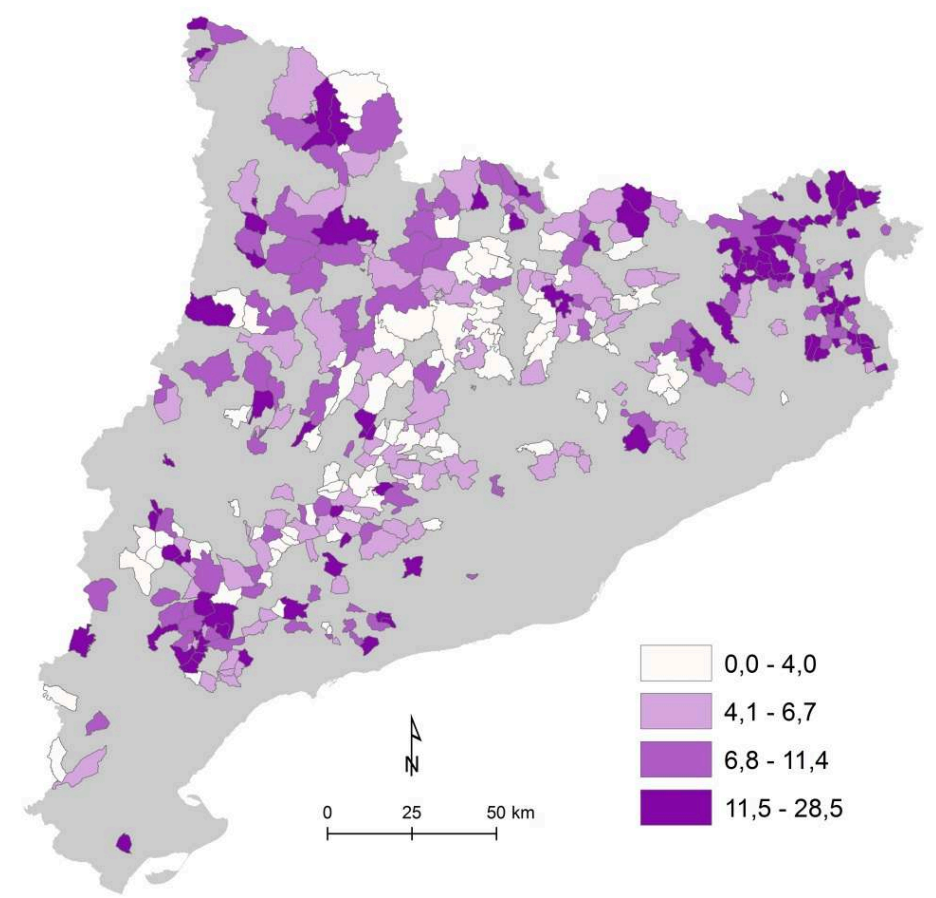

Source: HAMLETS research project, based on IDESCAT data (2019)

In spite of the challenges that the 2008 economic crisis posed across Southern Europe, foreign immigration remained very relevant in rural areas such as Alt Empordà (Morén-Alegret, Wladyka, 2019). This county is located in Girona province, one of the richest areas in Spain. In several Alt Empordà municipalities, local development heavily depends not only on labour provided by economic immigrants, but also on foreign investments in real estate and local businesses generated by the amenity/lifestyle migrants as well as on their daily life spending (Morén-Alegret, Wladyka, 2019). Apart from the role of Figueres as county capital, Alt Empordà contains very dynamic tourist coastal areas that include small and medium-size towns and a relatively large inland hinterland. The latter area is composed of a myriad of small villages whose main economic activities have progressively passed from farming to tourism. Alt Empordà is the county (i.e. comarca) of Catalonia containing the highest number of municipalities with fewer than 500 inhabitants: 29 municipalities (see Figure 2). Most of them are located in inland areas, with only one coastal exception. As can be appreciated in Figure 2, the area is well connected by motorway and high-speed train with Barcelona and Southern France as well as has a well-developed network of local roads. 
Figure 2. Municipalities with fewer than 500 inhabitants in Alt Empordà.

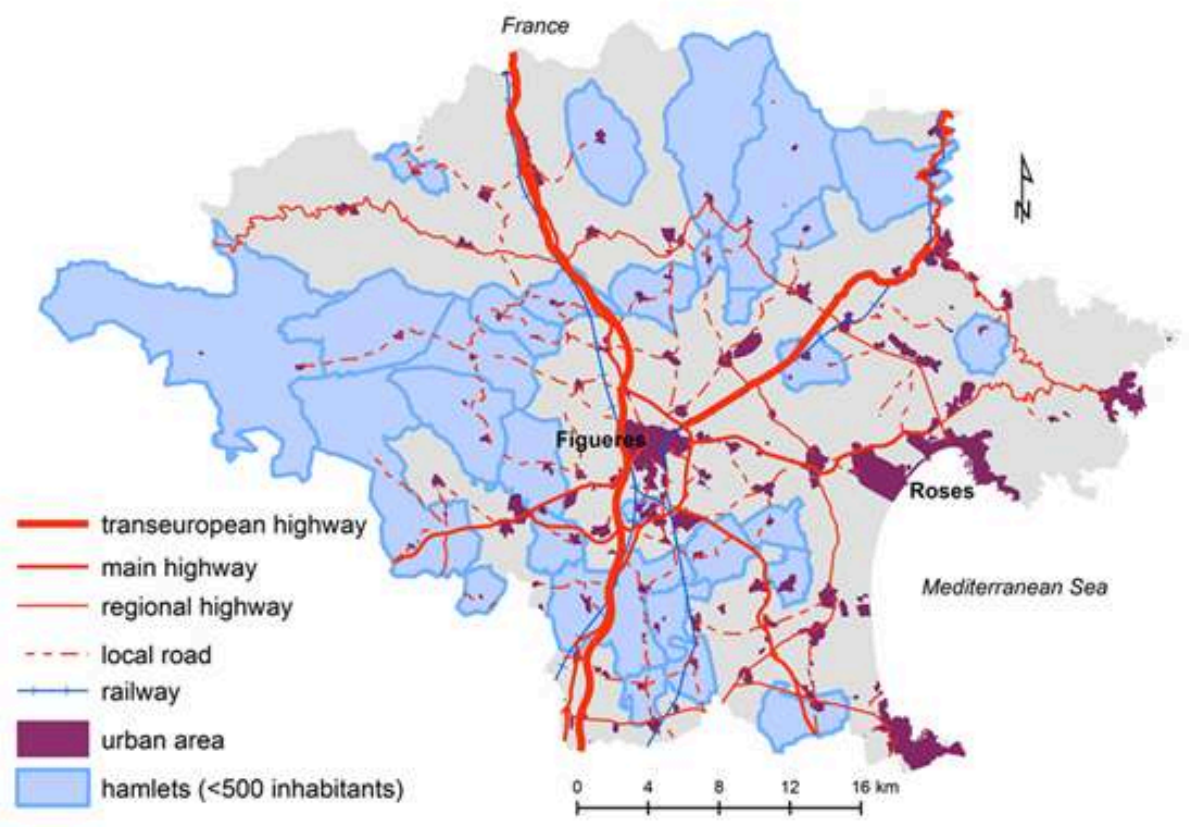

Source: Laia Mojica

\section{New and old economic activities: Innovation and original approaches towards rural economies}

In rural Spain and Europe, agriculture is increasingly specialised (Mora, San Juan 2004) and its survival depends, in many cases, on international labour (e.g. Hoggart, Mendoza, 1999; Rye, Scott, 2018) and on economic diversification strategies among farm household members, including rural tourism (e.g. Tulla, 2019). The following interview quotes from an immigrant employer who produces ecological wine with her Catalan husband illustrates this point. She decided to diversify by transforming an unoccupied building into tourist accommodation. This interviewee also describes the difficulties of getting funds from the Catalan public administration to develop her business plans:

The house besides the farm also belongs to us. We rebuilt it in order to accommodate tourist apartments in it with a clear idea of diversifying economic activities and risks. When we started, we asked for public funding, but it did not work, and we did it with our own money. We also wanted a rural lodge, but, since money did not come in, we renewed a wine cellar (Italian-born/48-year-old/ female/employer).

The aforementioned interviewee points out some relevant views on the traditional economic activities in Empordà. Her views display the porous boundaries between rural tourism and agriculture, including the challenges that accompany agriculture in the region; the need for entrepreneurs to adapt to changing markets; and the perception of increasing bureaucracy. Certainly, the drive towards a multifunctional countryside has been gaining pace and sustainable rural tourism has long been seen as a key component of rural development. Accordingly, the multifunctional countryside is conceived as 
'producing not only food but also sustaining rural landscapes, protecting biodiversity, generating employment and contributing to the viability of rural areas' (Potter, Burney 2002, p. 35).

Beyond farming and tourism, though, international immigrants also explore economic activities that are not well developed in Alt Empordà (Morén-Alegret and Wladyka, 2019). In particular, some foreign-born interviewees pointed at nature and landscape as having an intrinsic (economic) value and potential. Interestingly, some interviewed locally born entrepreneurs did not share these ideas, and also expressed more reluctance to business innovation than immigrant entrepreneurs. Indeed, for some immigrant entrepreneurs, their new homeland means a 'change of narrative'. For instance, Alt Empordà is perceived as the ideal place to develop a business aiming to help over-stressed highly-skilled transnational company employees. This immigrant retired from his previous academic activities and set up a training academy with his Spanish partner explaining:

Economically [what we need] is a change of narrative. We do company coaching, so people may think about their reason of being, their values, to incorporate all this in their company. It can last a year or so and they may come here or do the course via videoconference (Dutch-born/68-year-old male/self-employed).

Diversification opportunities were also identified in connection to the natural resources with some international immigrants considering that more sustainable economic initiatives could be implemented, helping small villages economies. In this regard, some interviewees indicated the potential of the Albera Natural Protected Area (NPA), a mountain park that may offer more activities for rural tourism. This is the case of an Italian entrepreneur with a rural lodge, which includes offering donkey promenades in the mountains:

I've got a second economic activity, donkey promenades. I do this with a [foreign] girl who lives in a neighbouring town. We met each other a few months ago. She offers promenades in the Albera's mountains. People start the route in my house. The first day is just a circle route to take care of the animals and get used to them. After that, the real promenade heads for the mountains for six days. She also has shorter routes. Customers are mainly Germans (Italian-born/60-year-old/male/ employer).

20 This kind of praxis resonates with Bunce's (2003: 15) ideas on rural space, as it "satisfies basic spiritual needs and [...] its landscapes stand as metaphors for associations buried deep in our memories, the rural idyll becomes a [...] response to the rise of urban civilisation". These ideals are well understood by a British self-employed woman who also identified the challenges of developing an environmental-friendly business:

I would design a green pathway connecting all the municipalities in the Albera area that would arrive to the sea ... In fact, these pathways already exist, but they are not in use any longer ... No one seems to be interested in an initiative like this. Indeed, bicycles could be rented in the villages, and small shops benefit from the path. This is the kind of tourism we need, linked to the environment, valuing it, caring for it. People coming from Northern Europe, from very urbanised settings, would appreciate it ... Initiatives coming from the municipalities are very limited and locals do not see beyond their limited interests (British-born/58-year-old/female/ self-employed).

21 Thus, among some immigrant entrepreneurs, there is a perception of future potential local ecological economic improvements in small villages of Alt Empordà. In this sense, the implementation of the European Green Deal ${ }^{2}$ might be helpful. However, the 
tensions between the economy, society and environment in the region have been noted elsewhere whereby powerful local actors constrain public authorities from creating new natural protected areas because some environmental regulations are perceived as a restriction for some types of economic development (Morén-Alegret et al., 2018). These tensions remain a significant barrier to overcome.

\section{Oiling up business: Social networking and the role of the territory}

For some people, the countryside seems a better "setting" for the fulfilment of some types of personal relationships than urban settings. Linked to this idea, the role of the territory and personal networks for business creation and consolidation in rural areas has been taken into account in the academic literature for a relatively long time (e.g. Stathopoulou et al., 2004; Esparcia et al., 2015). This territorial-based economic and social fabric is essential for preventing de-population and economic stagnation in many rural areas in Southern Europe. During our fieldwork, we noticed the relevance of social links based on personal connections and trust in both farming and tourist activities as well as the synergies created between these two economic sectors. An old male German immigrant entrepreneur was clear about all that:

I started with fruit trees and small farm 30 years ago in this piece of land you see. I bought it with all my savings. We started from scratch. Then we had geese, because an acquaintance opened a pâté and foie-gras factory. Later on, I met someone who told me about a German programme for abused youngsters. The programme consisted in sending these youngsters to isolated areas in order to help them reintegrate in society... I did it for 10 years. The German government paid it very well. With my savings, I built the rural lodges and I had this business for almost 10 years, but I had enough. Right now, I rent the houses to friends round the year... It's easier for me, and certainly it's less problematic (German-born/65-year-old/male/ employer).

For this latter immigrant, personal networking and relationships were critical in order to shift from one economic activity to another. To this respect, for some interviewees, business, friendship and social life go hand in hand, and, for some interviewed immigrants, it is something to take into consideration when moving into Spain, in line with the literature on lifestyle immigrants (e.g. Benson, Osbaldiston, 2014; Romagosa et al., 2020). This is the case for an interviewee who had many choices for working and living abroad, but selected Spain and, specifically, Alt Empordà. Her narrative is clear about how relevant social openness is for her:

We have worked in wineries around the world: South Africa, Australia, Chile and Spain. We like Spain very much... We found that Spanish people were more open. It's not far from Holland either. We can see our friends (...) Here, in Spain, we thought about the specific region and we decided to stay in Empordà. We love it, because of its great gastronomy. It is also close to the sea and there are not many organic producers (Dutch-born/28-year-old/female/employer).

This interviewee used social networks and relations not only to be successful in business, but also to achieve lifestyle objectives. The general message is that sustained social contacts and social incorporation are key aspects for the development/success of businesses in the area. This correlates with the aforementioned literature on ethnic entrepreneurship, which stressed the relevance of social networks for the creation of immigrant businesses. However, the difference lies in the fact that, for immigrants in 
general, intra-ethnic networks can be very important while, for the EU immigrant interviewees, networks are rarely based on immigrant bonds, but mainly on networks drawn from local society. The social networks of European immigrant entrepreneurs are built/expanded via an array of informal and formal channels, which may be enhanced by their status as "welcomed" foreigners, which help to include some mixed marriages (see Table 1). Northwest and Central European immigrants usually form part of "welcomed" immigrant groups in our study area. This 'positive stereotype' may have a clear impact for some European immigrant entrepreneurs in relation to making relevant contacts within the local economy, particularly in areas with a long tourism tradition like Empordà where a number of locally born people speak English, French and/or German. In this sense, social relations in rural areas can be fostered when both locally-born residents and immigrants are fluent in several languages (Morén-Alegret, Wladyka, 2019).

What becomes clear in the interviews is that the immigrants from Northwest Europe respond to a higher skills profile than other immigrants in the region working mainly in agriculture and typically from East Europe, Latin America and Africa. The interviewed immigrants fill a distinctive niche in the local labour economy, offering a variety of cultural-oriented services in several towns and villages and taking advantage of business opportunities in the region. This brings to mind the "opportunity structure" concept in migration literature (Rath, Kloosterman 2000; Kloosterman, 2010), in the sense that the specific characteristics of individual immigrant entrepreneurs combine with local labour market opportunities. It also affirms the idea of rurality offering an innovative and entrepreneurial milieu for small-scale enterprises (Stathopoulou et al. 2004).

\section{Lifestyle migration: Connections between economics, wellbeing and lifestyles}

When analysing the reasons for moving into Alt Empordà, lifestyle comes upfront in some narratives of international immigrants. The 'place idealisation' (Benson, Osbaldiston 2014, p. 9) was clear because there was evidence of interviewees idealising the notion of the village in their quest for a better way of life. This was based on somewhere they had previously lived, reflecting the imaginary of the idyllic rural (Hoggart, Buller, 1995; Boyle, Halfacree, 1998). The following interview extract from a British resident who supports her husband's language school and takes care of three children illustrates:

\footnotetext{
My husband and me like the countryside, we started to look around, and we saw the house. In 2017, we bought the house, nearly three years ago... For the children, it is fantastic, they have a lot of independence, they can move around, go with friends ... I myself grew up in a village, similar to [this] size, or slightly bigger. It was a hamlet, a workers' village of farms, back in the 1980s. Now it has changed a lot. In Britain, villages have changed completely. For me, [this village] reminds me of the village I grew up (...) There is a nice community here (British-born/41-year-old/female/ employer).
}

This woman refers to wellbeing and quality of life as influencing their decision to move to rural Catalonia. She also highlights the role of family in that decision, showing that lifestyle migration is more than an individual act, but is the result of household 
considerations (see also Kordel, Pohle, 2018). This is also the case for the following interviewees who actually opted for Alt Empordà because of their partners.

I used to work in an offset printing house in Germany. I met my wife who was Catalan in Nuremberg. She did not put up with the German lifestyle. So we packed up and came in here. We lived in different places around Spain, and finally we found this piece of land through some friends, and built everything from scratch (German-born/65-year-old/male/employer).

I met my husband in Milan when he was studying, and I followed him to Barcelona. We tried to live in Barcelona for a short time, but we made up our mind to move in here. His family has been living in this hamlet for four generations, and my husband inherited lands from them in 2006 (Italian-born/48-year-old/female/ employer).

On the other hand, four out of the twelve interviewed foreign-born immigrants combined a retirement (pension) from previous jobs with self-employment activities in Empordà. Interestingly enough, these people (re)entered labour markets as immigrant employers/self-employed workers after retirement as was the case for the Dutch immigrant described above who opened a training academy. He had left a permanent job at a public university back in the Netherlands to start his business in Catalonia. Wellbeing and the environment are important components of his business model. He advertises the importance of nature and environment for helping his clients to relax.

The interviewees appreciated the advantages of living in a rural setting with no-one discussing the possibility of moving out of Empordà in the near future. The statement "Have you seen this? Look around, this is paradise" made by a Dutch-born 48-year immigrant summarises sentiments. Alternatively, in a more functional way, others prefer to stress what they have reached so far, since better options are not foreseen. For instance, this is the case of a German-born 66-year-old self-employed immigrant who indicated the following: "Leaving this? No way. I put so much effort and time in building all this".

30 In a nutshell, lifestyle migration is not only triggered by the desire to escape the fast pace of urban life, but also represents a search for self-realization and a lifestyle change (Benson, O'Reilly, 2016). The aforementioned narratives also introduce the idea of wellbeing, and of being part of a community where friends and nature are a crucial part of their lives. Wellbeing is also a key issue for families with children and/or grandchildren in these municipalities, where kids can play freely in the streets, and they can walk to schools without supervision. This kind of easiness and desire for an attractive landscape is vividly articulated among international interviewees.

Not everything is idyllic though. Even if basic services are covered, specialised key services (e.g. hospitals) are concentrated in medium-sized and big cities. Due to a scarcely developed public transport network and despite a good network of local roads, those lacking a car may feel isolation. In fact, some interviewees reckon that there is out-migration of elderly people from small towns to neighbouring cities because they cannot drive to the county hospital. In this regard, a relatively young British interviewee who was quite happy with her decision to live in a small village also felt "stuck" in it, since the only family car was used by her husband to run the family business. She also told us during the interview that some community services for young children that are common in rural Britain are missing in rural Spain. Similarly, a Belgian immigrant complained about the lack of public transport in rural areas. 
According to her, there should be transportation tailored according to people's needs, as is the case in her country of origin. She believes that this is not be a luxury, but a necessity due to the needs of elderly people in rural areas. This interviewee also explained that when she had a health problem and applied to the public health service for nurse's assistance, the assistance was denied because she and her husband were considered to be wealthy enough to pay for it:

In Belgium, there is a bus in use when you need it, when you call it in. It is far better than a regular line. It is used when you really need it. It is even cheaper this way. My father needed to go to the doctor every day, and he had this service. A nurse is also needed for our villages, someone who could come home. Here practically all people pay for a nurse. A free nurse paid by public money is not a service for everyone. It is only for the poor. I had an accident, and I could not move from home for a while. I asked the village council about it, and they asked my wage. Their answer was that the service is restricted to those people without enough financial resources. But, a nurse is not luxury (Belgian-born/58-year-old/female/selfemployed).

The lack of public transportation is compensated by a dense network of roads covering Alt Empordà that connect the smallest villages in the area to the regional capital Figueres in approximately 20 minutes. The usually well-kept roads also ease commuting for many residents in some of these small villages. A young self-employed worker who is also mayor of one village in the Alt Empordà is clear about this: "We are a Figueres neighbourhood". Peri-urbanisation processes guarantee the survival of some small villages, but they make farming activities less desirable and there is a high risk of suburbanisation and gentrification of hamlets and villages, facing a real risk of becoming residential areas without any kind of services.

\section{Conclusions}

Focusing on small villages in Alt Empordà, this article has explored connections between local economies, entrepreneurship and lifestyle immigration. In doing so, two main lines of analysis have come up: the first one discussed the new and old activities in the region, stressing the role of social and economic networks that may become long-standing relations; the second one revolved around lifestyle immigrants and their connections with economic life. Interviewed immigrants from Northwest and Central Europe have a high skills profile, helping them to fill a distinctive niche in local labour markets and economies. They offer a variety of culturally-oriented services in several towns and villages. These high skilled immigrants take advantage of economic opportunities that Alt Empordà labour markets may offer and are not covered by locally born individuals (Morén-Alegret, Wladyka, 2019). They set up their own businesses in the area, in different places including hamlets. Of special relevance is the fact that some foreign-born interviewees see culture, nature and landscape as having an intrinsic (economic) value. Indeed, their appreciation of local resources is sometimes a major motivation for moving to rural areas (see also Bartoš et al., 2009; Iversen, Jacobsen, 2017). For some immigrant entrepreneurs, their new homeland means a change of narrative and contributes to the on-going emergence of a multifunctional countryside.

The interviewed immigrant entrepreneurs implicitly identify the relevance of personal networking for the success of their businesses and as a source of wellbeing. Previous 
research has highlighted the importance of intra-ethnic networks for migrant entrepreneurs, typically in an urban setting. Our research has shown how migrants to rural Catalonia rely on face-to-face social networks that are not based only on immigrant bonds, but on networks created in the host society. Given their small population, rural territories may thus be better placed than urban areas to develop these sorts of personal ties between newcomers and locally born entrepreneurs that enhance businesses rooted in the localities (see also Stathopoulou et al., 2004; Esparcia et al., 2015).

The cited reasons for moving into Empordà are not primarily related to the economy for most of the interviewees, but to personal motivations like their family's quality of life and a lifestyle change. The lifestyle immigration literature argues that, for certain groups, immigration is not only triggered by professional success and/or the desire to escape urban life, but also represents a search for self-realization and higher life standards (Benson, O 'Reilly, 2016). Certainly, the idealisation of rural places and the construction of particular destinations as idylls were evident as "a certain quest for a better way of life" (Benson, Osbaldiston, 2014, p. 7). Idealisation is sometimes built with childhood memories, lived or imagined. This may create problems if immigrants have idealised notions of how natural assets should be managed that conflict with local narratives that are focused on more traditional forms of economic development. Furthermore, the lifestyle immigrants in our study had various forms of capital (e.g. knowledge, education, finances) that afforded them to consider several life options, which may not be available to all residents in the area. This helps to create new types of innovative business in specific niche markets that, although not large in either financial terms or in relation to hired staff, may stimulate local rural development as well as help to strengthen values concerning sustainability and a sense of place and community (see also Ateljevic, Doorne, 2000). As a final reflection, our research suggests that lifestyle immigrants have the potential to re-imagine and rethink local culture and nature as possible successful business-oriented products, while also recognizing opportunities that locally born residents might ignore (see also Bosworth, Farrell, 2011; Mattsson, Cassel, 2019).

In March 2020, six months after the main fieldwork in Alt Empordà had been finished, the Spanish government declared the state of emergency to address the COVID-19 health crisis. Among other measures, the decree included the closure of international borders and harsh restrictions on internal mobility, which negatively affected the tourist sector. Although the alarm status ended in June 2020, and thus restrictions on internal mobility were lifted, several European countries have successively restricted trips from/to Spain. Moreover, in November 2020, new restrictions on internal mobility have been established in Spain. Although there are no scientific studies on the impact of COVID-19 on immigration in Europe, and particularly on immigrant businesses, some evidence can be gathered from an Internet search. As an example, in the forum of British immigrants in Spain, in April 2020, a businessman expressed himself about a perceived gloomy future: "I run a small local business and am not eligible for any of the assistance being offered by the Spanish government, unless I close down the company. I'm worried that if schools remain shut until september it will be very difficult to get back up and running at work, even if there are clients to sell to"3. However, during the summer of 2020 tourists from France, Belgium and, especially, the Netherlands were relevant in Girona province, including Alt Empordà ${ }^{4}$. In this sense, a relevant research question would be to inquire how the current economic crisis arising from COVID-19 
and how BREXIT could affect immigrant entrepreneurs in rural Southern European border areas (Bailoni, 2020), such as Alt Empordà5. Some issues like health authorities' restrictions for businesses might be relevant both for Spain-born and international immigrant entrepreneurs ${ }^{6}$, but we leave these questions for further research.

\section{BIBLIOGRAPHY}

ALDRICH H., WALDINGER R. (1990), “Ethnicity and entrepreneurship”, Annual Review of Sociology, 16, pp. 111-135.

AMCOFF J., WESTHOLM E. (2007), “Understanding rural change: Demography as a key to the future", Futures, 39, pp. 363-379.

ATELJEVIC I., DOORNE S. (2000), "Staying within the fence: Lifestyle entrepreneurship in tourism”, Journal of Sustainable Tourism, 8, pp. 378-392.

BAILONI M. (2020), « L'intégration internationale du Royaume-Uni post-Brexit: vers une reconfiguration de la régionalisation? », Belgeo, Belgian Journal of Geography, https://doi.org/ $10.4000 /$ belgeo.43852

BARTOŠ M., KUŠOVÁ D. \& TĚŠITEL J. (2009), "Motivation and lifestyle of the Czech amenity migrants", European Countryside, 3, pp. 164-179.

BAYONA-I-CARRASCO J., GIL-ALONSO F. (2013), "Is foreign immigration the solution to rural depopulation?: The case of Catalonia (1996-2009)”, Sociologia Ruralis, 53, pp. 26-51.

BELL M., OSTI G. (2010), “Mobilities and ruralities: An introduction”, Sociologia Ruralis, 50, pp. 199-204.

BENSON M.C. (2013), "Postcoloniality and privilege in new lifestyle flows", Mobilities, 8, pp. 313-330.

BENSON M., O'REILLY K. (2016), “From lifestyle migration to lifestyle in migration”, Migration Studies, 4, pp. 20-37.

BENSON M., O'REILLY K. (2009), “Migration and the search for a better way of life: A critical exploration of lifestyle migration", The Sociological Review, 57, pp. 608-625.

BENSON M., OSBALDISTON N. (2014), "New horizons in lifestyle migration research", in BENSON M., OSBALDISTON N. (eds.), Understanding Lifestyle Migration, London, Palgrave Macmillan, pp. $1-23$.

BOSWORTH G., FARRELL H. (2011), “Tourism entrepreneurs in Northumberland”, Annals of Tourism Research, 38, pp. 1474-1494.

BOYLE P., HALFACREE K. (1998), Migration into Rural Areas. Theories and Issues, New York, John Wiley \& Sons.

BUNCE M. (2003), “Reproducing rural idylls”, in CLOKE P. (ed.), Country Visions, Pearson, Harlow, pp. 14-30. 
CAMARERO L., SAMPEDRO R. (2019), “Despoblación y ruralidad transnacional”, Economía Agraria y Recursos Naturales, 19, pp. 59-82.

CARSON D.A., CARSON D.B. (2018), "International lifestyle immigrants and their contributions to rural tourism innovation”, Journal of Rural Studies, 64, pp. 230-240.

CARSON D.A., CARSON D.B. \& EIMERMANN M. (2018), "International winter tourism entrepreneurs in northern Sweden", Scandinavian Journal of Hospitality and Tourism, 18, pp. 183-198.

CLOKE P. (2013), Key Settlements in Rural Areas, London, Routledge.

CRAWLEY H., SKLEPARIS D. (2018), "Refugees, migrants, neither, both: Categorical fetishism and the politics of bounding in Europe's 'migration crisis', Journal of Ethnic and Migration Studies, 44, pp. 48-64.

EIMERMANN M., KORDEL S. (2018), "International lifestyle migrant entrepreneurs in two new immigration destinations”, Journal of Rural Studies, 64, pp. 241-252.

ESPARCIA J., ESCRIBANO J. \& SERRANO J.J. (2015), "From development to power relations and territorial governance", Journal of Rural Studies, 42, pp. 29-42.

FAIST T. (2000), The Volume and Dynamics of International Migration and Transnational Social Spaces, Oxford, Oxford University Press.

GARCÍA MARCHANTE J.S., VÁZQUEZ VARELA C., APARACIO GUERRERO A.E. \& MARTÍNEZ NAVARRO J.M. (2007), "La empresarialidad rural en el marco del desarrollo territorial”, Boletín de la Asociación de Geógrafos Españoles, 43, pp. 107-129.

GONZÁLEZ-HIDALGO M., OTERO I. \& KALLIS G. (2014), "Seeing beyond the smoke: The political ecology of fire in Horta de Sant Joan (Catalonia)”, Environment and Planning A, 46, pp. 1014-1031.

HANNAM K., SHELLER M. \& URRY J. (2006), “Mobilities, immobilities and moorings”, Mobilities, 1, pp. 1-22.

HAYES M. (2018), Gringolandia: Lifestyle Migration under Late Capitalism, Minnesota, University of Minnesota Press.

HEDLUND M., CARSON D.A., EIMERMANN M. \& LUNDMARK L. (2017), "Repopulating and revitalising rural Sweden? Re-examining immigration as a solution to rural decline", Geographical Journal, 183, pp. 400-413.

HOEY B. (2005), "From pi to pie: Moral narratives of noneconomic migration and starting over in the postindustrial Midwest”, Journal of Contemporary Ethnography, 34, pp. 586-624.

HOGGART K., BULLER H. (1995), "Retired British home owners in rural France”, Ageing and Society, 15, pp. 325-353.

HOGGART K., MENDOZA C. (1999), “African immigrant workers in Spanish agriculture”, Sociologia Ruralis, 39, pp. 538-562.

HUETE R., MANTENCÓN A. \& ESTÉVEZ J. (2013), “Challenges in lifestyle migration research”, Mobilities, 8, pp. 331-348.

IVERSEN I., JACOBSEN J.K.S. (2017), “Migrant tourism entrepreneurship in rural Norway”, Scandinavian Journal of Hospitality and Tourism, 16, pp. 484-499.

KALANTARIDIS C., BIKA Z. (2011), "Entrepreneurial origin and the configuration of innovation in rural areas", Environment and Planning A, 43, pp. 866-884. 
KING R., WARNES T. \& WILLIAMS A. (2000), Sunset Lives. British Retirement Migration to the Mediterranean, Oxford, Berg.

KING R., CELA E., MORETTINI G. \& FOKKEMA T. (2019), “The Marche: Italy's new frontier for international retirement migration", Population, Space and Place, https://doi.org/10.1002/psp. 2241.

KLOOSTERMAN R. (2010), "Matching opportunities with resources: A framework for analysing (migrant) entrepreneurship from a mixed embeddedness perspective", Entrepreneurship \& Regional Development: An International Journal, 22, pp. 25-45.

KORDEL S., POHLE P. (2018), "International lifestyle migration in the Andes of Ecuador", Sociologia Ruralis, 58, pp. 126-156.

MARSDEN T.K., MURDOCH J., LOWE P. \& WARD N. (2003), The Differentiated Countryside, Oxon, Routledge.

MATTSSON K.T., CASSEL S.H. (2019), "Immigrant entrepreneurs and potentials for path creating tourism development in rural Sweden”, Tourism Planning \& Development, https://doi.org/ 10.1080/21568316.2019.1607543.

MCAREAVEY R. (2017), New Immigration Destinations. Migrating to Rural and Peripheral Areas, New York, Routledge.

MCAREAVEY R., ARGENT N. (2018), “Migrant integration in New Immigration Destinations”, Journal of Rural Studies, 64, pp. 267-275.

MORA R., SAN JUAN C. (2004), "Geographical specialisation in Spanish agriculture before and after integration in the European Union”, Regional Science and Urban Economics, 34, pp. 309-320.

MORÉN-ALEGRET R. (2008), "Ruralphilia and urbophobia versus urbophilia and ruralphobia?", Population, Space and Place, 14, pp. 537-552.

MORÉN-ALEGRET R., FATORIČ S., WLADYKA D., MAS A. \& FONSECA M.L. (2018), “Challenges in achieving sustainability in Iberian rural areas and small towns", Journal of Rural Studies, 64, pp. 253-266.

MORÉN-ALEGRET R., WLADYKA D. (2019), International Immigration, Integration and Sustainability in Small Towns and Villages, London, Palgrave Macmillan.

MÜLLER D.K., JANSSON B. (2007), "The difficult business of making pleasure peripheries prosperous", in MÜLLER D., JANSSON B. (eds.), Tourism in Peripheries: Perspectives from the Far North and South, Wallingford, CAB, pp. 3-18.

OECD (2018), Rural 3.0: A Framework for Rural Development. Policy Note, Paris, OECD.

POTTER C., BURNEY J. (2002), “Agricultural multifunctionality in the WTO: Legitimate non-trade concern or disguised protection?", Journal of Rural Studies, 18, pp. 35-47.

RATH J., KLOOSTERMAN R. (2000), “Outsider's business: A critical review on immigrant entrepreneurship", Geopolitics, 34, pp. 657-681.

ROMAGOSA F., MENDOZA C., MÓJICA L. \& MORÉN-ALEGRET R. (2020), “Inmigración internacional y turismo en espacios rurales. El caso de los 'micropueblos' de Cataluña”, Cuadernos de Turismo, 46 (forthcoming).

RYE J.F. (2006), “Heading for the cities? Gender and lifestyle patterns in rural youths' residential preferences”, Norsk Geografisk Tidsskrift, 60, pp. 199-208. 
RYE J.F., SCOTT S. (2018), "International labour migration and food production in rural Europe", Sociologia Ruralis, 58, pp. 928-952.

SHELLER M., URRY J. (2006), “The new mobilities paradigm”, Environment and Planning A, 38, pp. 207-226.

SOMMER E., GAMPER M. (2018), “Transnational entrepreneurial activities: A qualitative network study of self-employed migrants from the former Soviet Union in Germany", Social Networks, 53, pp. 136-147.

STAM E. (2010), “Entrepreneurship, evolution and geography”, in BOSCHMA R., MARTIN R. (eds.), The Handbook of Evolutionary Geography, Cheltenham, Edward Elgar, pp. 139-161.

STATHOPOULOU S., PSALTOPOULOS D. \& SKURAS D. (2004), "Rural entrepreneurship in Europe: A research framework and agenda", International Journal of Entrepreneurial Behavior \& Research, 10, pp. 404-425.

STONE I., STUBBS C. (2007), "Enterprising expatriates: Lifestyle migration and entrepreneurship in rural Southern Europe", Entrepreneurship and Regional Development, 19, pp. 433-450.

TULLA A.F. (2019), "Sustainable rural development requires value-added activities linked with comparative advantage: The case of the Catalan Pyrenees", European Countryside, 11, pp. 229-256.

WILLIAMS A., KING R., WARNES A. \& PATTERSON G. (2000), “Tourism and international retirement migration: New forms of an old relationship in Southern Europe", Tourism Geographies, 2, pp. 28-49.

WOODS M. (2016), "International migration, agency and regional development in rural Europe", Documents d'Anàlisi Geogràfica, 62, pp. 569-593.

ZHOU M. (2004), "Revisiting ethnic entrepreneurship: Convergencies, controversies, and conceptual advancements", International Migration Review, 38, pp. 1040-1074.

\section{NOTES}

1. See: http://atlantis.uab.cat/hamlets/en/index.html

2. See: https://ec.europa.eu/info/strategy/priorities-2019-2024/european-green-deal_en

3. See: http://www.bremaininspain.com/articles/bremainmembers-in-lockdown/

4. For instance, see: https://www.diaridegirona.cat/comarques/2020/09/22/turisme-holandesconverteix-principal-usuari/1063759.html

5. For instance, see: https://www.diaridegirona.cat/catalunya/2020/07/25/els-francesosdesplacen-als-comercos/1054403.html

6. See: https://www.monrural.cat/2020/11/21/restaurants-de-pobles-petits-demanen-quesaixequi-el-confinament-municipal-de-cap-de-setmana-ens-estan-deixant-morir/ 


\section{ABSTRACTS}

The article studies connections between local economics, entrepreneurship and lifestyle immigration in municipalities with fewer than 500 inhabitants in Alt Empordà, Spain. Using a qualitative methodology, it analyses the economic incorporation of immigrant entrepreneurs by considering in which ways they contribute to the local economies. It also studies to what extent immigrant businesses follow purely economic benefit logics (or rather they are set up in search of a better quality of life). The interviewed immigrant entrepreneurs usually fit themselves in distinctive niches in local labour markets (e.g. cultural-oriented services). Their success partially relies in their capacities for creating locally based social networks, which are not only key aspects for business development, but also a source of wellbeing. This is in line with most lifestyle immigration literature, which argues that immigration is not only triggered by professional success, but also represents the search for self-realization and a higher quality of life.

L'article traite des liens entre les économies locales, l'entrepreneuriat et l'immigration mue par la recherche de qualité de vie dans les municipalités de moins de 500 habitants de l'Alt Empordà en Espagne. Avec une méthodologie qualitative, il analyse l'insertion économique des entrepreneurs immigrants, en examinant leurs contributions aux économies locales. Il examine également dans quelle mesure les entreprises immigrées poursuivent des logiques purement économiques ou sont aussi mises en place pour rechercher de meilleures qualités de vie. Les entrepreneurs immigrants interviewés s'inscrivent habituellement dans des niches spécifiques sur les marchés du travail locaux (par ex. les services culturels). Le succès de ces entreprises tient à leur capacité à créer des réseaux sociaux. Ces réseaux sont aussi une source de bien-être pour les personnes interrogées, outre qu'ils sont fondamentaux pour le succès de leurs affaires. Cela concorde avec la littérature sur les styles de vie, qui met en évidence que la migration n'est pas seulement déclenchée par la recherche d'une réussite professionnelle, mais qu'elle est aussi motivée par l'aspiration à la réalisation personnelle et à une meilleure qualité de vie.

\section{INDEX}

Mots-clés: migration de qualité de vie, entrepreneuriat, immigration internationale, zones rurales, économies locales, Espagne

Keywords: lifestyle migration, entrepreneurship, international immigration, rural areas, local economies, Spain

\section{AUTHORS}

\section{CRISTÓBAL MENDOZA}

Universidad Autónoma Metropolitana-Iztapalapa, cmp@xanum.uam.mx

\section{RICARD MORÉN-ALEGRET}

Universitat Autònoma de Barcelona, ricard.moren@uab.cat

\section{RUTH MCAREAVEY}

University of Newcastle, ruth.mcareavey@newcastle.ac.uk 